\title{
Pengaruh Penggunaan Substrat yang Berbeda Terhadap Pertumbuhan dan Kelangsungan Hidup Larva Rajungan (Portunus pelagicus)
}

\author{
Effect of Different Substrate Use on Growth and Survival of Crayfish (Portunus \\ pelagicus) Larvae
}

\author{
Agus Putra $\mathrm{AS}^{\mathbf{1}^{*}}$, Rini Mastuti ${ }^{2}$,Sorbakti Sinaga ${ }^{1}$ \\ ${ }^{1}$ Prodi Akuakultur Fakultas Pertanian Universitas Samudra, Langsa, Indonesia \\ ${ }^{2}$ Prodi Agribisnis Fakultas Pertanian Universitas Samudra, Langsa, Indonesia \\ *Korespondensi: agus.putra.samad@gmail.com
}

\begin{abstract}
ABSTRAK
Rajungan termasuk kedalam kelas Portunidae dan di beberapa negara kepiting ini terkenal sebagai komoditas ekspor.Penelitian ini dilakukan untuk menentukan substrat terbaik yang dapat meningkatkan kelangsungan hidup dan laju pertumbuhan Portunus pelagicus. Penelitian ini menggunakan rancangan acak lengkap dengan 4 perlakuan dan tiga ulangan.Perlakuan tersebut adalah: penggunaan substrat pasir $(\mathrm{P} 1)$, lumpur $(\mathrm{P} 2)$, kerikil (P3), dan kombinasi pasir dan kerikil (P4). Parameter yang diamati adalah tingkat kelangsungan hidup, berat dan panjang larva, rasio konversi pakan (FCR) dan kualitas air. Hasil penelitian menunjukkan bahwa tingkat kelangsungan hidup tertinggi terlihat pada P1 (33,67\%), pertambahan berat dan panjang terbaik terdapat pada P1 (1,69 gr dan 0,39 $\mathrm{cm})$ dan terendah pada P2 (1,54 gr dan 0,34 cm). Data menunjukkan bahwa FCR terbaik terdapat pada perlakuan P3 yaitu 3,92. Penelitian ini menunjukkan bahwa penggunaan substrat pasir memberikan pengaruh terbaik terhadap pertumbuhan dan kelangsungan hidup larva rajungan.
\end{abstract}

Kata kunci: Kelangsungan hidup; Pertumbuhan; Portunus pelagicus; Rajungan

\begin{abstract}
Swimming crab is a among Portunidae crab, and in some countries this crab is wellknown as an export commodity. The present study was done to determine the best substrate to improve survival and growth rate of Portunus pelagicus. This study used a completely randomized design with 4 treatments in triplicate. The treatments were: Sand (P1), Mud (P2), Gravel (P3), and Combination of Sand and Gravel (P4). The observed parameters were survival rate, larval weight and length, feed conversion ratio (FCR) and water quality. The results showed that the highest survival rate was seen at P1 (33.67\%), the best weight and length gain was at P1 $(1.69 \mathrm{~g}$ and $0.39 \mathrm{~cm})$ and the lowest was at P2 $(1.54 \mathrm{~g}$ and $0.34 \mathrm{~cm})$. Data showed that the best FCR is found in treatment P3 of 3.92,.This study showed that the use of sand substrate has the best effect on growth and survival during the rearing of crab larvae.
\end{abstract}

Keywords: Survival rate; Growth; Portunus pelagicus; Crab 


\section{PENDAHULUAN}

Indonesia merupakan negara kepulauan yang terbentang dari Sabang sampai Merauke, oleh karena itu Indonesia juga dikenal sebagai salah satu negara dengan garis pantai terpanjang di dunia (KKP, 2019). Dengan luasnya laut, Indonesia memiliki keanekaragaman flora dan fauna yang beragam (Syahrial et al., 2020). Hasil laut yang biasa ditangkap antara lain: tuna, udang, lobster dan rajungan. Dengan hasil perikanan yang melimpah, jika dikelola dengan baik. Indonesia akan menjadi negara yang memiliki ketahanan pangan paling baik di dunia (KKP, 2019). Rajungan merupakan jenis dari famili Portunidae. Namun karena kandungan proteinnya yang tinggi, kepiting ini termasuk krustasea yang banyak dicari nelayan. Saat ini rajungan merupakan komoditas unggulan ekspor produk perikanan Indonesia, khususnya ke Jepang, Uni Eropa dan Amerika Serikat (KKP, 2019; Effendy et al., 2006). Untuk mendapatkan informasi lebih lanjut tentang kepiting, penelitian ini dilakukan di perairan Langsa. Daerah ini dekat dengan Selat Malaka, sehingga masyarakatnya dominan bermata pencaharian sebagai nelayan. Hasil tangkapan nelayan di daerah ini sangat melimpah seperti: ikan, udang atau kepiting (Samad et al., 2020). Di kawasan ini, mereka selalu menangkap berbagai ukuran kepiting. Dengan demikian tidak ada kesempatan bagi kepiting ini untuk berkembang biak. Oleh karena itu, untuk mempertahankan populasinya, salah satu cara terbaik adalah dengan melakukan program budidaya atau breeding. Program pemuliaan adalah suatu metode penetasan hewan air dari telur menjadi larva hingga dewasa dalam lingkungan yang terkendali. Program pemuliaan sangat diperlukan dalam budidaya perikanan untuk menjaga stok benih di alam (Susanto et al., 2005). Selama proses pembibitan, lingkungan harus disiapkan sama seperti di habitat aslinya. Dengan demikian, substrat merupakan salah satu hal yang penting dalam percobaan ini. Substrat sangat berpengaruh terhadap kehidupan larva rajungan, oleh karena itu penting untuk mengetahui jenis substrat terbaik yang mampu meningkatkan kelangsungan hidup larva rajungan untuk mendukung stabilitas populasi rajungan baik di alam maupun budidaya. Penelitian ini bertujuan untuk mencari substrat terbaik untuk pertumbuhan dan kelangsungan hidup larva rajungan.

\section{METODE PENELITIAN}

\section{Rancangan Penelitian}

Metode yang digunakan pada penelitian ini adalah metode penelitian eksperimental dengan menggunakan Rancangan Acak Lengkap (RAL). Perlakuan yang diberikan terdiri dari empat perlakuan dan tiga kali pengulangan yaitu:

$$
\begin{aligned}
& \text { P1 }=\text { Substrat pasir. } \\
& \text { P2 }=\text { Subtrat lumpur. } \\
& \text { P3 }=\text { Subtrat kerikil. } \\
& \text { P4 }=\text { subtrat pasir dan kerikil } .
\end{aligned}
$$

\section{Persiapan Wadah}

Wadah yang digunakan sebagai tempat pengeraman telur berupa bak fiber yang berkapasitas $200 \mathrm{~L}$. Persiapan yang dilakukan dengan membuang air yang masih terdapat pada bak fiber, kemudian dilakukan penyikatan bak fiber untuk menghilangkan kerak kemudian membilasnya dengan air bersih, dan dilakukan pembilasan terakhir 
menggunakan air kaporit $100 \mathrm{ppm}$ sebagai desinfektan terhadap patogen.

\section{Seleksi Induk}

Induk rajungan ( $P$. pelagicus) diperoleh dari hasil tangkapan nelayan disekitar perairan Langsa. Induk betina sehat dicirikan dengan gerakan aktif, tidak keropos baik karapas maupun organ lain, dan kelengkapan organ tubuh. Kemudian berdasar pada parameter berat dan panjang karapas 100-300 gr untuk berat dan 10-15 cm untuk panjangnya. Induk rajungan $(P$. pelagicus) yang sudah memiliki telur ditebar pada wadah pengeraman (inkubasi). Padat tebar yang diterapkan adalah 1 ekor/150 L.

\section{Pengelolaan Kualitas Air}

Pengelolaan kualitas air pada bak pengeraman telur dengan cara mengganti air sebanyak $10 \%$ setiap harinya. Air yang digunakan untuk media pemeliharaan induk berasal dari air laut steril yang telah melalui filterisasi. Penggantian air dilakukan pada pagi hari pukul 08:00 pagi.

\section{Penetasan Telur dan Penebaran Larva}

Telur Rajungan terus mengalami perkembangan embrio, yaitu dari tingkat perkembangan embrio I hingga VII. Perkembangan embrio ini terlihat dari perubahan warna telur yang terjadi, yaitu kuning tua, keabu-abuan, kehitam-hitaman kemudian menetas. Setelah penetasan dilakukan pada bak inkubasi, larva yang baru menetas segera dipindahkan pada bak pemeliharaan. Sewaktu melakukan pemindahan dari bak inkubasi ke bak pemeliharaan harus dilakukan dengan sangat hatihati agar larva tidak stress dan mati.
Setelah telur Rajungan menetas menjadi larva (Zoea 1) maka seluruh larva sehat hasil panen dipindahkan ke bak-bak pemeliharaan larva. Penebaran larva dilakukan sesuai dengan kondisi lingkungan lama terhadap lingkungan baru (aklimatisasi) menjadi faktor penting yang harus diperhatikan. Kepadatan larva yang diterapkan adalah 50-100 larva/L.

Selama waktu pemeliharaan
larva, pakan yang diberikan
merupakan pakan alami dan pakan beku. Pakan alami seperti Rotifer diberikan setelah larva zoea ditebar ke bak pemeliharaan larva, pemberian rotifer dilakukan selama 8-9 hari yaitu pada awal tebar (D0) hingga hari ke-9 (D9) dengan kepadatan sebesar 10-15 ekor/ml. Pemberian naupli artemia pada hari ke-6 (D6) hingga larva Rajungan berkembang menjadi Crab 1 yaitu disaat umur pemeliharaan larva menginjak hari ke-13 atau 14. Awal pemeliharaan yaitu dari umur 5-6 hari naupli yang diberikan sebesar 15-20 ekor/ml/hari, ketika berumur 7-13 hari kepadatan Artemia meningkat 20-30 ekor/ml/hari. Pakan tersebut diberikan pada masa pemeliharaan megalopa sampai sebelum panen (C5-10) dengan dosis pakan yang digunakan 5-7 gr. Frekuensi pemberian pakan dilakukan 2 kali/hari.

\section{Pengumpulan Data Kelangsungan Hidup Rajungan}

Untuk melihat kelansungan hidup dari rajungan yang dibesarkan, makadilakukan perhitungan derajat sintasan menurut Effendi (1997), yaitu dengan rumus: $\mathrm{SR}=(\mathrm{Nt} / \mathrm{N} 0) \mathrm{x}$ $100 \%$. 


\section{Laju Pertumbuhan Rajungan}

Laju pertumbuhan spesifik rajungan sangat dipengaruhi oleh jumlah dan kualitas pakan yang diberikan. Untuk melihat pertumbuhan rajungan maka akan dihitung dengan menggunakan rumus Samad et al. (2014) yaitu: LPS = (ln $\mathrm{wt}-\ln \mathrm{w} 0) / \mathrm{t}$ x $100 \%$.

\section{Feed Convertion Ratio (FCR)}

Untuk menghitung FCR dapat menggunakan rumus (Samad et al., 2014) sebagai berikut:

$\mathrm{FCR}=\frac{\text { Pakan dikonsumsi }(g)}{\text { Berat akhir }(g)-\text { Berat awal }(g)}$

Data yang diperoleh selanjunya dianalisis dengan analisis varian (ANOVA).

\section{HASIL DAN PEMBAHASAN}

\section{Kelangsungan Hidup Larva Rajungan}

Hasil pengamatan rata-rata kelangsungan hidup larva rajungan selama 10 hari terlihat pada Tabel 1. Analisis sidik ragam menunjukkan bahwa substrat yang berbeda berpengaruh nyata terhadap kelangsungan hidup larva rajungan.

Tabel 1. Rata-rata kelangsungan hidup larva rajungan ( $P$. pelagicus)

\begin{tabular}{cc}
\hline Perlakuan & $\begin{array}{c}\text { Kelangsungan hidup } \\
\text { larva rajungan }(P . \\
\text { pelagicus })(\%)\end{array}$ \\
\hline P1 & $33,67 \pm 2,02^{\mathrm{c}}$ \\
P2 & $13,00 \pm 2,08^{\mathrm{a}}$ \\
P3 & $17,67 \pm 1,20^{\mathrm{a}}$ \\
P4 & $24,33 \pm 0,33^{\mathrm{b}}$ \\
\hline
\end{tabular}

Keterangan: Huruf yang berbeda pada baris yang sama menunjukkan pengaruh perlakuan yang berbeda nyata $(\mathrm{P}<0,05)$.

Pada Tabel 1. menunjukkan kelangsungan hidup larva terbaik terdapat pada perlakuan P1 yaitu :
$33,67 \%$ (substrat pasir) sedangkan kelangsungan hidup terendah ditemui pada perlakuan P2 yaitu : $13,00 \%$ (substrat lumpur).

\section{Pertumbuhan Berat Larva Rajungan}

Hasil pengamatan rata-rata pertumbuhan berat larva rajungan terlihat pada Tabel 2. Analisis sidik ragam menunjukkan bahwa substrat yang berbeda berpengaruh nyata terhadap pertumbuhan berat larva rajungan.

Tabel 2. Rata-rata pertambahan berat larva rajungan ( $P$. pelagicus)

\begin{tabular}{cc}
\hline Perlakuan & $\begin{array}{c}\text { Pertambahan berat larva } \\
\text { rajungan }(P . \text { pelagicus }) \\
\text { (gr) }\end{array}$ \\
\hline P1 & $1,69 \pm 0,040^{\mathrm{c}}$ \\
P2 & $1,54 \pm 0,033^{\mathrm{a}}$ \\
P3 & $1,60 \pm 0,016^{\mathrm{ab}}$ \\
P4 & $1,62 \pm 0,056^{\mathrm{ab}}$ \\
\hline
\end{tabular}

Keterangan: Huruf yang berbeda pada baris yang sama menunjukkan pengaruh perlakuan yang berbeda nyata $(\mathrm{P}<0,05)$.

Pada Tabel 2. terlihat bahwa P1 memiliki pertambahan berat terbaik dengan rata-rata 1,69 gr sedangkan rata-rata pertumbuhan terendah terlihat pada P2 yaitu 1,54 gr. Berdasarkan hasil uji Duncan menunjukkan bahwa P1 berbeda nyata dengan $\mathrm{P} 2$.

\section{Pertumbuhan Panjang Larva Rajungan}

Hasil pengamatan rata-rata pertumbuhan panjang larva rajungan adalah seperti terlihat pada Tabel 3 . Analisis sidik ragam menunjukkan bahwa substrat yang berbeda menunjukkan pengaruh nyata terhadap pertumbuhan panjang larva rajungan. 
Tabel 3. Rata-rata pertumbuhan panjang larva rajungan ( $P$. pelagicus)

Perlakuan Pertumbuhan panjang larva rajungan (P.pelagicus) $(\mathrm{cm})$

\begin{tabular}{cc} 
& P1 \\
P2 & $0,39 \pm 0,00^{\mathrm{b}}$ \\
P3 & $0,37 \pm 0,00^{\mathrm{ab}}$ \\
P4 & $0,34 \pm 0,00^{\mathrm{a}}$ \\
\hline
\end{tabular}

Keterangan : Huruf yang berbeda pada baris yang sama menunjukkan pengaruh perlakuan yang berbeda nyata $(\mathrm{P}<0,05)$.

Pada Tabel 3. terlihat bahwa perlakuan terbaik terdapat pada perlakuan P1 dengan rata-rata pertumbuhan panjang: $0,39 \mathrm{~cm}$, sedangkan pertumbuhan panjang terendah terlihat pada perlakuan P3 yaitu $0,34 \mathrm{~cm}$.

\section{Rasio Konversi Pakan}

Hasil pengamatan terhadap rasio konversi pakan adalah seperti terlihat pada Tabel 4. Analisis sidik ragam menunjukkan bahwa substrat yang berbeda menunjukkan pengaruh nyata terhadap FCR larva rajungan.

Tabel 4. Rata-rata Rasio konversi pakan larva rajungan ( $P$. pelagicus)

\begin{tabular}{cc}
\hline Perlakuan & $\begin{array}{c}\text { FCR larva rajungan } \\
\text { (P. pelagicus) }\end{array}$ \\
\hline P1 & $6,69 \pm 0,20^{\mathrm{c}}$ \\
P2 & $4,01 \pm 0,43^{\mathrm{a}}$ \\
P3 & $3,92 \pm 0,86^{\mathrm{a}}$ \\
P4 & $5,77 \pm 0,36^{\mathrm{b}}$ \\
\hline
\end{tabular}

Keterangan: Huruf yang berbeda pada baris yang sama menunjukkan pengaruh perlakuan yang berbeda nyata $(\mathrm{P}<0,05)$.

Pada Tabel diatas menunjukkan bahwa FCR terbaik terdapat pada perlakuan P3 3,92, sedangkan FCR tertinggi terdapat pada perlakuan $\mathrm{P} 1$ sebesar 6,69.

\section{Kualitas Air}

Hasil pengamatan rata-rata kualitas air selama penelitian terlihat pada Tabel 5. Rata-rata kualitas air menunjukkan kualitas air yang konstan dan seragam dari seluruh perlakuan.

Tabel 5. Rata-rata kualitas air larva rajungan

\begin{tabular}{lcccc}
\hline \multirow{2}{*}{$\begin{array}{c}\text { Perlaku } \\
\text { an }\end{array}$} & \multicolumn{4}{c}{ Perlakuan } \\
\cline { 2 - 5 } & $\mathrm{P} 1$ & $\mathrm{P} 2$ & $\mathrm{P} 3$ & $\mathrm{P} 4$ \\
\hline $\begin{array}{l}\text { Suhu } \\
\left({ }^{\circ} \mathrm{C}\right)\end{array}$ & 30,17 & 29,33 & 29,40 & 29,23 \\
$\begin{array}{l}\text { Salinitas } \\
\text { (ppt) }\end{array}$ & 25,15 & 25,00 & 25,61 & 25,54 \\
$\begin{array}{l}\text { DO } \\
\text { (ppm) }\end{array}$ & 5,14 & 5,43 & 5,43 & 5,48 \\
pH & 7,34 & 7,56 & 7,46 & 7,53 \\
\hline
\end{tabular}

Pada Tabel 5. Terlihat bahwa suhu air pada setiap pengamatan tertinggi yaitu $30,17^{\circ} \mathrm{C}(\mathrm{P} 1)$ dan suhu terendah yaitu $29,23^{\circ} \mathrm{C}$. Salinitas air pada penelitian tertinggi pada perlakuan P3 (25,61 ppt) dan terendah pada perlakuan P2 (25,00 ppt). Oksigen terlarut tertinggi pada $\mathrm{P} 4$ $(5,48 \mathrm{mg} / \mathrm{l})$ sedangkan terendah pada $\mathrm{P} 1(5,14 \mathrm{mg} / \mathrm{l})$. Tingkat keasaman air (pH) pada pengamatan menunjukkan $\mathrm{pH}$ tertinggi pada perlakuan $\mathrm{P} 2(7,56)$ dan $\mathrm{pH}$ terendah pada perlakuan $\mathrm{P} 1$ $(7,34)$.

Tingkat kelangsungan hidup larva rajungan merupakan modal dasar dalam kegiatan pembenihan rajungan. Tingkat kelangsungan hidup merupakan perbandingan larva awal pertama ditebar dengan akhir pengamatan dan dinyatakan dalam bentuk persen. Semakin tinggi nilai persentase tingkat kelangsungan hidup maka perlakuan yang diberikan semakin baik (Effendi, 2002). Dalam penelitian ini diperoleh hasil bahwa penggunaan substrat yang berbeda berpengaruh signifikan terhadap kelangsungan hidup larva rajungan (Tabel 1). Hal ini sesuai dengan pendapat Stevens \& Swiney (2005), yang menyebutkan bahwa beberapa 
jenis organisme akan menjadikan shelter sebagai tempat berlindung dari predator dan kanibalisme terutama pada saat megalopa dan zoea. Namun, hasil eksperimen ini berbeda dengan penelitian yang dilaporkan oleh Djunaidi (2009), bahwa substrat pasir, lumpur dan liat tidak berpengaruh terhadap tingkat kelulushidupan larva rajungan. Rajungan mampu hidup pada substrat dasar perairan yang berbeda dengan populasi yang berbeda (Susanto at al., 2004). Selanjutnya Budiaryani (2007) menambahkan bahwa rajungan hidup pada habitat yang beraneka ragam seperti pasir, pasir berlumpur dan juga laut terbuka pada kedalaman hingga 50 meter. Rajungan pada masa megalopa akan menunjukkan sifat agitasi yang sangat tinggi sehingga mengakibatkan mortalitas yang tinggi. Adanya peluang berlindung akan meningkatkan kehidupan larva rajungan, selain itu, kualitas shelter dan substrat juga mampu mengurangi kanibalisme.

Selama penelitian ini, kondisi wadah pemeliharaan seperti: kualitas air dan ketersediaan pakan senantiasa diatur sesuai dengan kebiasaan hidup rajungan. Hal ini dilakukan karena selain substrat terdapat pula faktor lain yang dapat mempengaruhi kelangsungan hidup larva rajungan. Susanto et al. (2005) menyebutkan bahwa faktor yang mempengaruhi kelangsungan hidup organisme terdiri atas 2 yaitu faktor internal dan eksternal. Faktor internal merupakan parasit, hormon, infeksi penyakit, stress, genetik, dan umur. faktor eksternal yaitu suhu, oksigen, pakan dan turbiditas.

Pertumbuhan larva rajungan bersifat diskontinyu yang terjadi setelah terjadinya proses ganti kulit (molting) yaitu ketika kulit luar belum mengeras secara sempurna. pada saat molting terjadi proses kalsifikasi yang merupakan proses penyerapan kalsium dari lingkungan melalui proses osmotik. Keberadaan ion kalium berkaitan dengan aktivitas enzim $\mathrm{Na}+\mathrm{K}+\mathrm{ATPase}$ mampu meningkatkan proses osmoregulasi. Kalium termasuk logam yang esensial yang diperlukan dalam proses fisiologis yang terikat dalam protein termasuk enzim metabolisme pada rajungan (Taqwa at al., 2012). Berdasarkan pengamatan yang dilakukan pada larva rajungan yang dipelihara dengan substrat berbeda menunjukkan pertumbuhan berat dan panjang yang berbeda. Fatmawati (2009) menyebutkan bahwa pertumbuhan pada rajungan ditandai dengan pertambahan ukuran panjang dan berat setelah proses molting. Ada beberapa faktor yang mempengaruhi proses pertumbuhan yaitu ukuran makanan yang tersedia, suhu, oksigen, umur, dan ukuran organisme. Pertambahan panjang pada larva rajungan terjadi setelah terjadinya proses molting. Fujaya at al. (2013) menyebutkan bahwa siklus molting terdiri dari molt, postmolt, intermolt, dan premolt. Astuti (2008) menambahkan bahwa pertumbuhan panjang pada larva rajungan dipengaruhi oleh habitat hidupnya, dimana larva yang dipelihara dengan habitat yang berbeda akan menghasilkan pertumbuhan yang berbeda pula.

Nilai konversi pakan (FCR) yang tidak sama menunjukkan penyerapan yang tidak maksimal pada larva rajungan dengan substrat yang berbeda. Jumlah konsumsi pakan akan berbeda pada setiap ukuran dan populasi larva rajungan. Larva rajungan yang memiliki ukuran besar akan mengkonsumsi pakan yang lebih 
banyak. Semakin kecilnya nilai FCR menunjukkan pakan yang diberikan semakin efisien (Josileen, 2013). Hasil pengamatan FCR (Tabel 4) lebih jernih sehingga memudahkan larva rajungan dalam menangkap makanan yang diterima. Tingginya nilai FCR $(3,92$ - 6,69) pada larva rajungan dikarenakan pada awal penelitian rajungan masih menyesuaikan diri dengan substrat yang berbeda sehingga banyak larva rajungan mengalami kematian dan pakan tidak dikonsumsi secara efisien. Hal ini sesuai dengan pendapat Sugama, (2006) dan Yuniasari, (2009) bahwa stress mengakibatkan kehilangan nafsu makan.

Kualitas air memegang peranan penting dalam kegiatan budidaya. Air pada media pengamatan yang menurun dapat mengakibatkan larva rajungan stress, pertumbuhan terhambat, terserang penyakit, peningkatan rasio konversi pakan, dan mati. Kualitas air yang sangat penting adalah suhu, salinitas, $\mathrm{pH}$, dan DO. Hasil pengamatan rata-rata suhu pada penelitian berkisar antara 29,23-30,17 ${ }^{\circ} \mathrm{C}$. Hal ini memperlihatkan suhu perairan pada penelitian sesuai dan mendukung kehidupan larva rajungan yang

\section{KESIMPULAN}

Substrat pasir, lumpur, kerikil dan pasir berkerikil menghasilkan tingkat kelangsungan hidup, pertumbuhan panjang, pertambahan berat dan rasio konversi pakan (FCR) yang berbeda nyata $(\mathrm{P}<0,05)$. Berdasarkan pengamatan diketahui bahwa penggunaan substrat pasir menghasilkan kelangsungan hidup dan pertumbuhan yang terbaik. menunjukkan bahwa perlakuan pada P3 (substrat kerikil) memiliki FCR terbaik yaitu 3,92. Hal ini disebabkan karena kualitas air pada perlakuan ini bersifat euritermal yaitu berkemampuan beradaptasi pada kisaran suhu yang luas. Hal ini sesuai pendapat Astuti (2008), bahwa kisaran suhu yang baik untuk rajungan adalah $27-31^{\circ} \mathrm{C}$. Hasil pengamatan salinitas pada penelitian yaitu 25,00-25,61 ppt. Hal ini masih layak pada kehidupan larva rajungan. Lantu (2010), menyatakan bahwa rajungan merupakan hewan yang mampu mengatur osmoregulasinya dengan baik. Hasill pengamatan $\mathrm{pH}$ perairan juga menunjukkan angka 7,34-7,56. Hal ini memperlihatkan $\mathrm{pH}$ perairan pada penelitian telah memenuhi syrat kehidupan larva rajungan. Hal ini didukung oleh pernyataan Astuti (2008) yang menyatakan bahwa nilai $\mathrm{pH}$ untuk budidaya larva rajungan berkisar antara 7,2-8,6. Oksigen terlarut (DO) pada pengamatan menunjukkan angka 5,14-5,48 ppm. Oksigen terlarut di dalam air dibutuhkan untuk berespirasi serta hidup normal. Hal ini sesuai dengan pendapat Astuti (2008) bahwa rajungan membutuhkan DO berkisar antara 4,00-6,00 ppm.

\section{DAFTAR PUSTAKA}

Astuti, O. (2008). Pengaruh Salinitas Terhadap Perkembangan dan Kelangsungan Hidup Larva Menjadi Megalopa Rajungan (Portunus pelagicus). Pasca Sarjana Institut Pertanian Bogor. Bogor. 
Budiaryani, G.J. (2007). Quantitative analysis of marine biological communities: field biology and environment. John Wiley \& Sons, Inc. $411 \mathrm{pp}$.

Effendi. 2002. Biologi Perikanan. Cetakan Kedua. Yayasan Pustaka Nusantara. Yogyakarta. 163.

Effendy, S., Sudirman, S., Bahri, E., Nurcahyono, H., Batubara., \& M. Syaichudin. (2006). Petunjuk Teknis Pembenihan Rajungan (Portunus pelagicus L). Diterbitkan Atas Kerjasama Departemen Kealutan dan Perikanan, Direktorat Jenderal Perikanan dengan Balai Budidaya Air Payau. Takalar

Djunaedi, A. (2009). Kelulushidupan dan Pertumbuhan Crablet Rajungan (Portunus pelagicus Linn.) pada Budidaya dengan Substrat Dasar yang Berbeda. Universitas Diponegoro: Semarang.

Fatmawati. (2009). Kelimpahan Relatif dan Struktur Ukuran Rajungan diDaerah Mangrove Kecamatan Tekolabbua Kabupaten Pangkep. Universitas Hasanuddin. Makassar.

Fujaya, Y., Trijuno , D. D., Hasnidar. (2013). Pengaruh Siklus Bulan Terhadap Dinamika Hormon Ecdysteroid Kaitannya dengan Aktivitas Molting Kepiting Bakau (Scylla olivacea) pada Budidaya Kepiting Cangkang Lunak. Laporan penelitian fundamental. Universitas Hasanudin. Makassar. 1-7.
Josileen, J. (2013). Fecundity of the blue swimmer crab, Portunus pelagicus (Linnaeus, 1758) (Decapoda, Brachyura, Portunidae) along the coast of Mandapam, Tamil Nadu, India. Crustaceana, 86(1): 48-55.

KKP. (2019). Laporan Tahunan 2018. Biro Perencanaan, Sekretariat Jenderal Kementerian Kelautan dan Perikanan. Jakarta. 120 p. https://kkp.go.id/artikel/13937laporan-tahunan-kkp-2018

Samad, A.P.A., Hua, N.F., Chou, L.M. (2014). Effects of stocking density on growth and feed utilization of grouper (Epinephelus coioides) reared in recirculation and flow-through water system. African Journal of Agricultural Research, 9 (9). 812-822

Samad, A.P.A., Agustina, P., Herri, M. (2020). Kajian Nilai Ekonomis dan Dampak Sosial Keberadaan Ekosistem Mangrove Terhadap Masyarakat Pesisir. Jurnal Ekonomi dan Pembangunan. 11 (1), 1-10.

Stevens, B.G., Swiney, K.M. (2005). Post-settlement effects of habitat type and predator size on cannibalism of glaucothoe and juveniles of red king crab Paralithodes camtscaticus. Journal of Experimental Marine Biology and Ecology. Volume 321 (1). 1-11.

Sugama, K., Novita, H., Koesharyani, I. (2006). Production 
Performance, Diseases, SPFBreeding and Risk Issues Concerning White Shrimp, Penaeus vannamei, Introduction Into Indonesia. Indonesian Aquaculture Journal. 1 (1).

Susanto, B., Marzuqi, M., Setiyadi, I., Syahidah, D., Permana, G.N., Haryanti. (2004). Pengamatan aspek biologi rajungan (Portunus pelagicus), dalam menunjang teknik perbenihannya. Warta Penelitian Perikanan Indonesia. 10 (1): 6-11.

Susanto, B., Setyadi, I., Haryanti., Hanafi, A. (2005). Pedoman Teknis Teknologi Perbenihan Rajungan (Portunus pelagicus), Pusat Riset Perikanan, Jakarta. 21.

Syahrial, S., Saleky, D., Samad, A.P.A., Tasabaramo, I.A. (2020). Ekologi Perairan Pulau Tunda Serang Banten: Keadaan Umum Hutan Mangrove. Jurnal Sumberdaya Akuatik Indopasifik. 4 (1): 53-68.

Taqwa, F. H., Ade, D.S., Karim, G. (2012). Kelangsungan Hidup, Kerja Osmotik dan Konsumsi Oksigen Pasca Larva Udang Galah Selama Penurunan Salinitas dengan Air Rawa Pengencer Yang Ditambahkan Kalium. Prosiding InSINas. 98102.

Yuniasari, D. (2009). Pengaruh Pemberian Bakteri Nitrifikasi dan Denitrifikasi serta Molase dengan C/N Rasio Berbeda Terhadap Profil Kualitas Air, Kelangsungan Hidup, dan
Pertumbuhan Udang Vaname (Litopenaeus vannamei). Institut Pertanian Bogor. Bogor. 78 . 
